\title{
The Influence of Chemical Element on Properties of Deformed Steel Bar*
}

\author{
Ruixiang Han1, Menghui Hu¹, Qian Pei', Dianxuan Gong1\#, Yunxia Song² \\ ${ }^{1}$ Mathematical Modeling Association, North China University of Science and Technology, Tangshan, China \\ ${ }^{2}$ Tangshan College, Tangshan, China \\ Email:"wgdxidname@gmail.com
}

How to cite this paper: Han, R.X., Hu, M.H., Pei, Q., Gong, D.X. and Song, Y.X. (2016) The Influence of Chemical Element on Properties of Deformed Steel Bar. Open Journal of Statistics, 6, 1174-1180. http://dx.doi.org/10.4236/ojs.2016.66095

Received: October 25, 2016

Accepted: December 23, 2016

Published: December 28, 2016

Copyright $\odot 2016$ by authors and Scientific Research Publishing Inc. This work is licensed under the Creative Commons Attribution International License (CC BY 4.0).

http://creativecommons.org/licenses/by/4.0/

\begin{abstract}
In this paper, the relationship between steel and chemical elements is explored. A production record of a steel mill is adopted for two years, which is used as the basic data to standardize the data. Then, according to the correlation coefficient method between the hot-rolled ribs No. 1 and No. 2 hot-rolled ribs, the correlation between the two sets of data is analyzed. The main influencing factors of the hot-rolled ribs properties are obtained qualitatively. Then, the logistic regression method is used. Finally, according to the national standard of Chinese steel, the linear optimization model of $\mathrm{Cr}$ and $\mathrm{Mn}$ and $\mathrm{V}$ elements was established, and the change range of $\mathrm{Cr}$ was obtained without affecting the performance of hot rolled ribs.
\end{abstract}

\section{Keywords}

Correlation Analysis, Logistic Regression, Linear Optimization Model, Hot-Rolled Ribbed Bar

\section{Introduction}

Hot-rolled ribbed bar is commonly known as deformed steel bar, it's mainly used for skeleton of reinforced concrete component and it requires certain mechanical strength, bending and deformation properties, fabrication weldability in use. Most deformed steel bar adopts microalloying method, that is to add expensive microelement (such as $\mathrm{Mn}$ alloy material, $\mathrm{V}$ alloy material, etc.) into steel, adjust the composition proportion and to improve structure property. In this paper, by collecting the mechanical properties of steel types, the main mechanical properties are hardness, tensile strength, yield strength, toughness [1] [2] [3] [4], brittleness, percentage elongation after fracture and ${ }^{\star}$ The work was supported by the National Natural Science Foundation of China (No. 11301120, No. 11601151), the Natural Sceince Foundation of Hebei Province (No. A2015209189) and the Young Talents Project of Hebei Province. 
so on. Many factors affect the mechanical properties; this article only considers the effect of chemical elements. First of all, we explore the types of chemical elements, analysis of mechanical properties of steel. The relationship between the chemical element and the steel performance index was analyzed through the production data of a steel enterprise for two years. The main and minor factors that affect the three mechanical properties are obtained. Then, we analyze the major and the minor degree of the chemical elements by the correlation analysis and analysis. In it, we find the mechanical relationships between the main elements and the three mechanical indices. Finally, through the construction of mathematical models, we found their impact relationship. In practice, business managers take into account the price of rare metals, and $\mathrm{Cr}$ in the hot-rolled ribs to add excess, the impact of Mn and V. Combined with China's national hot-rolled rib of the national standards, a linear optimization model was established. By optimizing the model [5], the range of $\mathrm{Cr}$ is obtained under the condition of not affecting the performance of hot-rolled ribs. When the company uses mine rich in $\mathrm{Cr}$, the $\mathrm{Cr}$ content in liquid iron will significantly increase. Therefore there is a question: When $\mathrm{Cr}$ content increases, can we reduce alloy material amount in order to control the cost?

\section{Data Preprocessing}

From the experience of daily life, combined with scientific and technical literature and steel production data, the data are standardized. Data between the different dimensions, resulting in a large difference between the data directly to deal with it is difficult to find the chemical elements, the conclusion is very unfavorable. Therefore, this paper firstly standardized data processing, the extreme value method as a standard data processing. After the data have been processed by extreme values, all data will be in the range $(0,1)$.

Extreme value processing formula:

$$
X_{i j}=\frac{x i j-m j}{M j-m j}
$$

In it, $M_{j}=\max \left\{X_{i j}\right\}$ is the maximum value in the matrix and $m_{j}=\min \left\{X_{i j}\right\}$ is the minimum value in the matrix. Here are some of the data after the standardization, see Table 1.

Take No. 1 and 2 specifications of steel, the position of the front three.

Table 1. Standardized data.

\begin{tabular}{ccccccccc}
\hline Specification & $\mathrm{C}$ & $\mathrm{Mn}$ & $\mathrm{S}$ & $\mathrm{P}$ & $\mathrm{Si}$ & $\mathrm{Ceq}$ & $\mathrm{V}$ & $\mathrm{Cr}$ \\
\hline 1 & 0.5 & 0.4483 & 0.65 & 0.25 & 0.5294 & 0.375 & 0.0977 & 0.0698 \\
1 & 0.5 & 0.2759 & 0.9 & 0.5 & 0.3529 & 0.3125 & 0.1203 & 0.1047 \\
1 & 0.5 & 0.4138 & 0.5 & 0.0833 & 0.5588 & 0.3125 & 0.1053 & 0.093 \\
2 & 0.5 & 0.4138 & 0.75 & 0.3333 & 0.4706 & 0.5 & 0.1128 & 0.1163 \\
2 & 0.5 & 0.5517 & 0.85 & 0.5556 & 0.3824 & 0.3125 & 0.1128 & 0.1047 \\
2 & 0.3333 & 0.4138 & 0.625 & 0.4444 & 0.4118 & 0.3125 & 0.0977 & 0.1163 \\
\hline
\end{tabular}




\section{Mathematical Modeling}

\subsection{Correlation Analysis}

The main properties of the deformation of steel are yield strength, tensile strength and elongation after fracture, other mechanical properties are not considered, the subject mentioned: the chemical composition of steel is the ultimate structural properties of hot-rolled steel is the basic elements. Therefore, the factors affecting the performance of steel only consider the chemical element effects, and analysis of the primary and secondary relationship between these elements.

Data sampling area is an important means of data processing in modern mathematics. In this paper, sample processing method is used to classify the No. 1 and No. 2 steel materials on the basis of ensuring the order of standardization of raw data. Ribs 71 sets of data, No. 2 hot-rolled ribs 51 sets of data, were studied.

The hot-rolled ribs of No. 1 and the No. 2 hot-rolled ribs are separated, and the correlation between each element and the three properties and the three properties are analyzed respectively. The product correlation coefficient method is used to calculate the correlation between the element and the performance. The formula of the product correlation coefficient is as follows:

$$
r_{i j}=\frac{\sum_{1}^{50}(x-\bar{x})\left(y_{i}-\bar{y}\right)}{\sqrt{\sum_{1}^{50}(x i-\bar{x})^{2} \sqrt{\sum_{1}^{50}\left(y_{i}-\bar{y}\right)^{2}}}}
$$

In it, $r_{i j}$ is the correlation coefficient.

The following table shows the correlation between the individual elements and the three properties:

With the MATLAB program, standardize the data. According to Table 2 and Table 3 , we can find the main factors affecting the yield strength of hot-rolled ribs are $\mathrm{C}, \mathrm{Si}$, $\mathrm{Cr}, \mathrm{P}, \mathrm{S}$, and the main factors affecting tensile strength are $\mathrm{C}, \mathrm{Si}, \mathrm{Mn}, \mathrm{P}, \mathrm{S}, \mathrm{Cr}$ affect the elongation of the main elements of $\mathrm{P}, \mathrm{C}, \mathrm{Mn}$.

\subsection{Construction of Mathematical Models}

It is well known that the properties of the hot-rolled ribs directly affect the metallurgical

Table 2. The correlation between each element of No. 1 hot-rolled rib and three properties.

\begin{tabular}{cccccccccccccc}
\hline & $\mathrm{C}$ & $\mathrm{Mn}$ & $\mathrm{S}$ & $\mathrm{P}$ & $\mathrm{Si}$ & $\mathrm{Ceq}$ & $\mathrm{V}$ & $\mathrm{Cr}$ & $\mathrm{Ni}$ & $\mathrm{Cu}$ & $\mathrm{Mo}$ & $\mathrm{Alt}$ \\
\hline Tensile strength & 0.348 & 0.12 & -0.128 & 0.117 & 0.246 & -0.207 & -0.05 & -0.311 & 0.06 & 0.059 & -0.16 & -0.17 \\
Yield strength & 0.331 & 0.002 & 0.473 & -0.301 & 0.244 & 0.076 & -0.092 & -0.134 & -0.25 & -0.085 & 0.933 & 0.98 \\
Percentage elongation after fracture & -0.114 & 0.099 & -0.026 & 0.449 & 0.082 & -0.124 & 0.195 & -0.351 & 0.099 & 0.187 & 0.159 & 0.158 \\
\hline
\end{tabular}

Table 3. Correlations of the individual elements of No. 2 hot-rolled ribs with the three properties.

\begin{tabular}{cccccccccccccc}
\hline & $\mathrm{C}$ & $\mathrm{Mn}$ & $\mathrm{S}$ & $\mathrm{P}$ & $\mathrm{Si}$ & $\mathrm{Ceq}$ & $\mathrm{V}$ & $\mathrm{Cr}$ & $\mathrm{Ni}$ & $\mathrm{Cu}$ & $\mathrm{Mo}$ & $\mathrm{Alt}$ \\
\hline Tensile strength & 0.3 & 0.175 & -0.136 & 0.16 & 0.212 & -0.064 & -0.046 & -0.299 & 0.02 & 0.046 & -0.52 & -0.053 \\
Yield strength & 0.362 & 0.028 & 0.21 & -0.258 & 0.192 & 0.082 & -0.149 & -0.279 & -0.141 & -0.045 & 0.737 & 0.98 \\
Percentage elongation after fracture & -0.028 & 0.163 & -0.125 & 0.102 & -0.144 & -0.114 & -0.413 & 0.249 & 0.316 & 0.028 & 0.17 & 0.136 \\
\hline
\end{tabular}


properties of the hot-rolled ribs and the yield point and tensile strength of the hot-rolled ribs increase with the increase of the $\mathrm{C}$ content and the properties and impact properties are decreased. In the steelmaking process, the manganese is good Deoxidizer and desulfurization agent, the general steel containing manganese $0.3 \%$ $0.5 \%$ [6] [7] [8], compared with ordinary steel not only has enough toughness, as well as high strength and hardness. According to the need, the manganese content increases, reduces the steel the corrosion resistance ability, reduces the welding performance. Chromium in the hot-rolled ribs can significantly improve the strength, hardness and wear resistance, while reducing the plastic toughness, but also improve the oxidation resistance and corrosion resistance of steel, nickel can improve the strength of steel to maintain good plasticity and toughness of the acid Alkali has a strong resistance to corrosion, but nickel is more scarce, it should be considered with other elements instead of cadmium and nickel. Si can remarkably improve the elastic limit, yield strength and fatigue property of steel.

The yield strength, tensile strength and elongation at break of the deformed steels were compared with those of $\mathrm{C}, \mathrm{Mn}, \mathrm{Cr}, \mathrm{V}$ and $\mathrm{Ni}$, including $\mathrm{C}, \mathrm{Cr}, \mathrm{V}, \mathrm{Ni}$.

The data of $\mathrm{C}, \mathrm{Mn}, \mathrm{Cr}, \mathrm{V}$ and $\mathrm{Ni}$ are taken as the independent variable's vectors $x_{1}, x_{2}, x_{3}, x_{4}, x_{5}$. The yielding strength, the tensile strength after breaking and the elongation at break were taken as $y$ variables, and the conditional probability was assumed.

$$
P=p\left(y=1 \mid x_{i}\right)
$$

In the formula, $p$ is the probability of observing the occurrence of something. According to the data, we can get the regression model. The relation between $y_{j}$ and $x_{1}, x_{2}, x_{3}, x_{4}, x_{5}$ is as follows:

$$
E(y)=p_{i}=f\left(x_{1}, x_{2}, x_{3}, x_{4}, x_{5}\right)
$$

In the formula, the function $f(x)$ is the monotonic increasing function of the range in $[0,1]$ interval.

For logistic regression:

$$
F(y)=e^{\wedge} x /\left(e^{\wedge} x+1\right)
$$

$Y_{i}$ is the distribution of the mean value $p_{i}=f\left(x_{1}, x_{2}, x_{3}, x_{4}, x_{5}\right)$ between $[0,1]$, the probability is:

$$
\begin{gathered}
P\left(y_{i}=1\right)=p_{i} \\
P=\left(y_{i}=0\right)=1-p_{i}
\end{gathered}
$$

The probability of the number of $Y_{i}$ written together:

$$
P\left(y_{i}\right)=p_{i}^{y i}(1-p)^{1-y i} ; y i=0, i=1,2,3,4,5
$$

The maximum likelihood of $Y_{1} Y_{2} Y_{3}$ is:

$$
R=\prod_{1}^{N} P\left(y_{i}\right)=\prod_{I=1}^{N} p_{i}^{y_{i}}(1-p)^{1-y_{i}}
$$

Take the natural logarithm, the formula is: 


$$
\begin{gathered}
\ln R=\sum_{i=1}^{n}\left(y_{i} \ln p_{i}+(1-y i)\right) \ln \left(1-p_{i}\right) \\
y=k_{0}+k_{1} x_{1}+a_{2} x_{2} * G
\end{gathered}
$$

$G$ is the residual, and then do linear regression with MATLAB, can be drawn with the yield strength of $\mathrm{Mn}, \mathrm{C}$ off

$$
Y_{1}=6.4 \mathrm{C}-0.51 \mathrm{Mn}+0.345
$$

With the corrcoef function can be seen in the specifications of a steel, $\mathrm{Ni}, \mathrm{Cr}, \mathrm{V}$ and tensile strength of a linear relationship. This shows that the linear relationship is satisfied in the plane:

$$
y=k_{3}+k_{4} x_{3}+k_{6} x_{5}+k_{5} x_{4} * G_{1}
$$

$G_{1}$ is the residual, and then do linear regression with MATLAB, can be drawn with the yield strength, $\mathrm{Cr}, \mathrm{Ni}, \mathrm{V}$ relationship is as follows:

$$
y_{2}=0.175 \mathrm{Cr}+2.165 \mathrm{Ni}+0.679 \mathrm{~V}+0.566
$$

The comprehensive relationship between the five major elements of $\mathrm{Mn}, \mathrm{C}, \mathrm{Cr}, \mathrm{Ni}, \mathrm{V}$ and the yield strength can be summarized as follows:

$$
\begin{gathered}
Y=6.43 \mathrm{C}-0.52 \mathrm{Mn}+0.174 \mathrm{Cr}+2.165 \mathrm{Ni}+4.34 \mathrm{~V} \\
z=q_{0}+q_{1} x_{1}+q_{2} x_{2}+T
\end{gathered}
$$

$T$ Is the residual, and then do linear regression with MATLAB, C, Mn and fracture tensile strength relationship is as follows:

$$
z_{1}=703.22 \mathrm{C}+82.44 \mathrm{Mn}+79.567
$$

Using the corrcoef function, it can be seen that the tensile strength of $\mathrm{Cr}, \mathrm{Ni}, \mathrm{V}$ and fracture is approximately linear in the steel with the size of one. This shows that the linear relationship is satisfied in the plane:

$$
z_{2}=805.4 \mathrm{Cr}+509 \mathrm{Ni}+5446.677 \mathrm{~V}+679.678
$$

$T$ Is the residual, and then do a linear regression with MATLAB, C, Mn, Cr, Ni, V and fracture tensile strength relationship is as follows:

$$
z=704.5 \mathrm{C}+82.44 \mathrm{Mn}+805 \mathrm{Cr}+509 \mathrm{Ni}+5446.677 \mathrm{~V}+732
$$

$C$ and elongation at break linearly. This shows that the linear relationship is satisfied in the plane:

$$
L=u_{0}+u_{1} x_{1}+u_{2} x_{2} * Q
$$

$Q$ Is the residual, and then do linear regression with MATLAB, can be drawn with the yield strength of $\mathrm{Mn}, \mathrm{C}$ relationship is as follows:

$$
L_{1}=1.53 \mathrm{C}-0.5 \mathrm{Mn}+0.45
$$

With the corrcoef function can be seen in the specifications of a steel, $\mathrm{Ni}, \mathrm{Cr}, \mathrm{V}$ and tensile strength of a linear relationship. This shows that the linear relationship is satisfied in the plane:

$$
L_{2}=u 3+u 4 \times 3+u 6 \times 5+u 5 \times 4 * Q_{1}
$$

$Q_{1}$ is the residual, and then do linear regression with MATLAB, can be obtained 
with the yield strength, $\mathrm{Cr}, \mathrm{Ni}, \mathrm{V}$ relationship is as follows:

$$
L_{3}=0.5 \mathrm{Cr}+0.65 \mathrm{Ni}+0.69 \mathrm{~V}+0.57
$$

The comprehensive relationship between the five major elements of $\mathrm{Mn}, \mathrm{C}, \mathrm{Cr}, \mathrm{Ni}, \mathrm{V}$ and the elongation at break is as follows:

$$
L=1.53 \mathrm{C}-0.65 \mathrm{Mn}+0.78 \mathrm{Cr}+2.1 \mathrm{Ni}+4.34 \mathrm{~V}
$$

Similarly, the relationship between the yield strength, the tensile strength and the elongation at break of $\mathrm{C}, \mathrm{Mn}, \mathrm{Cr}, \mathrm{V}$ and $\mathrm{Ni}$ in the specification II can be obtained as follows:

$$
\begin{aligned}
Y & =6.43 \mathrm{C}-0.52 \mathrm{Mn}+0.174 \mathrm{Cr}+2.165 \mathrm{Ni}+4.34 \mathrm{~V} \\
L & =1.37 \mathrm{C}-0.75 \mathrm{Mn}+0.8 \mathrm{Cr}+2.0005 \mathrm{Ni}+4.06 \mathrm{~V}
\end{aligned}
$$

Through the above formula can be concluded:

The carbon content of steel increased, yield strength and tensile strength increased, but the plastic and lower impact;

Mn can improve the toughness of sufficient to improve its [7] [8] [9] tensile strength and flexural strength to improve the tensile properties of chromium to reduce steel, can improve the antioxidant capacity, nickel can improve the strength of steel to maintain shape.

\subsection{Analysis $\mathrm{Cr}$, Optimization Ratio}

According to the third question, the mathematic model of the performance of the hot-rolled ribs is established, and the mathematical model of the linear programming is established through the second group of equations and the Chinese national standard [10]. The relationship between C, Mn, Cr, V, Ni and the tensile strength and elongation at break were obtained. The functional formulas were as follows ((19), (25), (26):

Here, the HPB335 and HPB400 are discussed according to the Chinese national standard.

HB335 hot-rolled ribs linear programming model: (27); HB400 hot-rolled ribs linear programming model: (28).

$$
\begin{aligned}
& \left\{\begin{array}{l}
Z=455 \\
Y=335 \\
L=17 \\
0.17<\mathrm{C}<0.25 \\
0.1<\mathrm{Ni}<0.14 \\
0.08<\mathrm{Cr}<0.2
\end{array}\right. \\
& \left\{\begin{array}{l}
Z=540 \\
Y=400 \\
L=16 \\
0.17<\mathrm{C}<0.25 \\
0.1<\mathrm{Ni}<0.14 \\
0.08<\mathrm{Cr}<0.2
\end{array}\right.
\end{aligned}
$$

Through calculating of the $\mathrm{HB} 335$ hot-rolled ribs, the range of $\mathrm{Cr}$ is:

$0.08<\mathrm{Cr}<0.16$. 
Through calculating of the HB400 hot-rolled ribs, the range of $\mathrm{Cr}$ is:

$0.0924<\mathrm{Cr}<0.1679$.

The range of $\mathrm{Mn}$ and $\mathrm{V}$ in HB335 was calculated: $1.23<\mathrm{Mn}<1.48 \quad 0.24<\mathrm{V}<0.35$.

The range of $\mathrm{Mn}$ and $\mathrm{V}$ in $\mathrm{HB} 400$ was calculated: $1.25<\mathrm{Mn}<1.503$

$0.28<\mathrm{V}<0.36$.

\section{Conclusion}

In this paper, it is divided into three parts: Analyzing the performance and main influencing factors of hot-rolled ribs, establishing the mathematical model between chemical elements and properties, analyzing the range of $\mathrm{Cr}$ content without affecting the performance, achieving energy saving and emission reduction, economic and rational development purposes.

\section{References}

[1] Xu, Y. (2002) Current Application Situation of $400 \mathrm{MPa}$ Hot Rolled Ribbed Bar in China and Some Suggestions for Its Development. Steel Rolling, 19, 3-6.

[2] Wan, W.G. and Zhao, M.Q. (2005) Research on the Variations in Tensile Properties of Hot Rolled Ribbed Bar after Aging. Physical Testing and Chemical Analysis Part A: Physical Testing, 41, 275-279.

[3] Wu, X.X. (1980) Talk about the Chemical Elements on the Performance of Steel. Construction Workers, 6, 013.

[4] Wang, S. (2006) Effects of Microalloying and Rapid Cooling on the Microstructure and Properties of Hot Rolled Ribbed Bar. Northeastern University.

[5] Yan, G., Yang, J.Y., Chuang, W., et al. (2011) Effects of Alloying Elements on Matrix and Properties in Low Alloy Steels. Journal of Shenyang Normal University (Natural Science Edition), 29, 510-513.

[6] Zhan, S.Y. Research on Seismic Behavior of Reinforcing Steel Bars.

[7] Shen, X.P. (1999) Analysis and Improvement of the Quality of Hot Rolled Ribbed Bars. Jiangsu Metallurgy, 27, 10-11.

[8] Parthé, E., Gelato, L., Chabot, B., et al. (2013) TYPIX Standardized Data and Crystal Chemical Characterization of Inorganic Structure Types. Springer Science \& Business Media, USA, $260 \mathrm{p}$.

[9] Hu, R. (2007) Multi-Output Support Vector Regression Algorithm. Journal of East China Jiaotong University, 24, 129-132.

[10] Ma, C.F. (2010) Optimization Method and Its Matlab Program Design. Science Press, Beijing. 
Submit or recommend next manuscript to SCIRP and we will provide best service for you:

Accepting pre-submission inquiries through Email, Facebook, LinkedIn, Twitter, etc. A wide selection of journals (inclusive of 9 subjects, more than 200 journals)

Providing 24-hour high-quality service

User-friendly online submission system

Fair and swift peer-review system

Efficient typesetting and proofreading procedure

Display of the result of downloads and visits, as well as the number of cited articles

Maximum dissemination of your research work

Submit your manuscript at: http://papersubmission.scirp.org/

Or contact ojs@scirp.org 